\title{
Employment and Economic Growth in Costa Rica
}

\author{
Gary S. Fields* \\ Cornell University
}

\begin{abstract}
Summary
Costa Rica's economic growth in the last 25 years has had favorable labor market and income distribution consequences. Overall, employment growth kept pace with labor force growth, the mix of jobs improved, real wages rose, and relative inequality and absolute poverty fell. But during the economic crisis of 198082, when real per capita income plummeted, labor market conditions deteriorated markedly: unemployment doubled, employment composition worsened, and real wages fell by $40 \%$. Growth, labor market conditions, and income distribution have moved together.
\end{abstract}

\section{Introduction}

This paper documents labor market and income distribution developments in the context of economic growth in Costa Rica in the last 25 years. Costa Rica, like many Latin American economies, enjoyed generally favorable macroeconomic conditions in the 1960s and 1970s. However, in 1980, macroeconomic events, and the policy response to them, forced a severe readjustment with a consequent recession so profound that it is termed throughout Costa Rica "the crisis." All economic indicators registered pronounced declines. Real GNP per capita fell by some $18 \%$. Inflation reached $90 \%$. Unemployment doubled. Real wages plummeted by $40 \%$. Payments on foreign debts were suspended. The Costa Rican economy bottomed out in 1982. It seems to be well on the road to recovery today.

Among the questions to be answered in this paper are these. What happened to unemployment during the economic growth of the 1960s and 1970s? To real wage levels? To the composition of employment? To relative income inequality and absolute poverty? How are we to understand these labor market and income distribution patterns in terms of macroeconomic events in the country? Once the crisis hit, what happened to labor market conditions and income distribution? Were some industries, localities, or sectors affected more than others? Why? How have conditions in the labor market improved, if at all, during the macroeconomic recovery of the last few years? What are the prospects for future improvements? What policies are most appropriate?

\section{Growth in the 1960s and Early 1970s}

We begin our review of the Costa Rican experience in the early 1960s. That was an important time both in terms of

\footnotetext{
* This report was prepared with financial support from the United States Agency for International Development (USAID). Helpful discussions with Robert Adler and Minor Sagot are gratefully acknowledged.
} 
economic events and in terms of data availability. The economic event of greatest importance at that time was the entry of Costa Rica into the Central American Common Market in 1963, an event which had important macroeconomic consequences, described below. In terms of data, the first comprehensive survey of income distribution in Costa Rica was conducted in 1961 and a Census of Population, including detailed labor market information, was carried out in 1963. These data serve as a benchmark for comparisons with subsequent dates.

\section{(a) Conditions in the early $1960 \mathrm{~s}$}

The Costa Rican economy around 1960 looked like this. Gross National Product (GNP) was US \$336 per capita (1961). The major economic activities were agriculture (26\% of Gross Domestic Product (GDP)), wholesale and retail trade (21\%), and manufacturing (15\%). Exports accounted for about 30\% of GDP. These exports were comprised largely of agricultural crops - coffee, bananas, meat, sugar, and cocoa.

The labor force in 1963 reflected the production structure. 63\% of the labor force was rural then. Nearly half of the labor force (49.7\% to be exact) was employed in the agricultural sector. Manufacturing accounted for $11.7 \%$ of employment at that time and construction for another $5.5 \%$. The remaining $33.1 \%$ of the labor force was divided among services, commerce, transportation, and other miscellaneous activities. The public sector was a significant employer even then, accounting for $13.3 \%$ of total employment and a substantially larger fraction of modern sector employment. (Precise figures are not available.) The unemployment rate stood at $6.9 \%$ of the total labor force - hardly full employment but not at crisis levels either.

One outstanding feature of Costa Rica in comparison with many Latin American countries is the relatively equal distribution of income and wealth. Land was (and continues to be) relatively equally distributed in Costa Rica compared to many other Latin American countries. Education was widespread, only $15 \%$ of those employed having had no education in 1963. Income inequality was moderate by Latin American standards, the Gini coefficient among households standing at 0.52 in Costa Rica in 1961 compared with 0.44 in Argentina, 0.54-0.57 in Mexico, 0.45 in Puerto Rico, and 0.54 in Venezuela around the same time (Jain, 1975). These .aspects of relative socioeconomic equality reflect a progressive orientation toward development which continues in Costa Rica up to the present time.

\section{(b) Macroeconomic events and policies in the 1960s and early 1970 s}

In the early 1960s, Costa Rica shifted its macroeconomic orientation. Up to that time, it had been following a development strategy that was also being pursued throughout much of Latin America. That strategy, known as "import substitution," entailed the production within the country of products that previously had been imported; hence domestic production substitutes for imports. The goals of import substitution are to become more self-sufficient as a nation and to engender economic growth through use of domestic resources, especially labor, in the productive process.

In the case of Costa Rica, import substitution led to the growth of certain industries, because they were highly protected by high tariffs against outside competition. That is, domestic producers were shielded against foreign competition, which enabled them to expand sales, but at higher prices than consumers would have had to pay had they been able to buy 
goods and services from lower-cost foreign firms.

The Central American Common Market (CACM) was formed in 1963. The countries of the CACM reduced barriers to trade among themselves and erected Common External Tariffs against imports from other countries. Entry into the CACM afforded the opportunity for Costa Rica to expand exports to other Central American countries. This they did. Manufactured exports increased many-fold, from 4\% of total exports in 1963 to $29 \%$ in 1979. At its height, 80\% of Costa Rica's manufactured exports were going to other CACM countries. These products could not have been sold in the larger world market - prices were simply too high. Thus, the formation of the CACM and Costa Rica's entry into it afforded an intermediate trade strategy - more open with respect to other Central American countries, but highly protectionist with respect to the rest of the world - which might be termed export-led growth within a regionally protected framework. This was not export-led growth of the East Asian type.

Meanwhile, exports of traditional agricultural products continued to grow. In the words of Gonzälez-Vega (1984): "Exports of coffee, bananas, sugars, and beef have raised the levels of domestic output and income, increased the country's import capacity, and yielded many of the dynamic benefits of specialization."

Overall, the economy of Costa Rica grew at an average annual rate of 6.5\% in real terms between 1960 and 1970 . By way of comparison, growth rates of GDP were $7.6 \%$ in Mexico in that interval, $5.4 \%$ in Brazil, $5.1 \%$ in Colombia, $4.9 \%$ in Peru, and 4.3\% in Argentina (World Bank, 1984, Table 2). Thus, the Costa Rican economy was one of the fastest growing ones in Latin America at that time. Growth rates of such a magnitude imply that real GDP was twice as high in 1971 as in 1960. Thus the first years of export-led growth within the CACM framework were clearly a macroeconomic success for Costa Rica.

\section{(c) Changes in labor markets and income distribution in the 1960s and early 1970 s}

The central question to which this paper is addressed is: who benefited from different epochs of Costa Rican economic growth? In particular, what happened to employment and unemployment, job composition, real wages, inequality, and poverty? From the early 1960s to the early 1970s, the data for Costa Rica show considerable improvements along most of these dimensions, as shown by the following figures.

\section{(i) Unemployment}

The unemployment rate was $6.9 \%$ in $1963,7.3 \%$ in 1973 - a slight increase. During that time, the labor force grew at an annual rate of $2.5 \%$, yet employment almost kept pace due to economic growth.

\section{(ii) Employment by activity status}

The labor force is categorized by activity status in Costa Rican statistics. The categories used are wage earners, employers and self-employed workers, non-remunerated family workers, and new entrants to the labor force. In the course of economic development, a pattern observed around the world is the influx of workers into wage-earner status and out of self-employment and non-remunerated family work, which are lower-paying and hence less desirable. In the earlier stages of economic development, selfemployment (in street vending, say) is frequently an activity of last resort, 
taken up by those who cannot obtain wage jobs in factories or offices. Movements into wage employment therefore represent improved earning opportunities. Such improvements transpired in Costa Rica between 1963 and 1973. The share of wage-earners in the Costa Rican labor force went from $66 \%$ in 1963 to $74 \%$ in 1973 - a sign of progress given wage- earners' higher earnings. This reflected shifts of equal amounts out of employer and selfemployment status (from $21 \%$ of the labor force in 1963 to $17 \%$ in 1973) and out of non- remunerated family work (from $10 \%$ to $6 \%$ ). This is one indication of the fact that economic growth brought the workers of Costa Rica better jobs than they had had a decade earlier.

\section{(iii) Sectoral mix of employment}

Another concomitant of successful economic growth is the movement of workers out of low-paying sectors of the economy, especially agriculture, and into higher-paying sectors. In Costa Rica, between 1963 and 1973, the share of the labor force employed in agriculture fell from $49.7 \%$ to $38.2 \%$. The workers released from agriculture did not go into unemployment; instead they went into the better-paying sectors of the economy. Table 1 displays the percentage change in employment in various economic sectors in the 1963-73 period for each major sectoral group, and shows that the highest-paying sectors were those that exhibited the highest rates of increase in employment. What was taking place was that the higher-income sectors of the economy were expanding, many of them because of exports or export-related activities.

With this expansion came the need for more labor. The increased demand for labor was filled partly by employing new entrants to the labor force and partly by attracting workers from other economic sectors by offering them higher rates of pay. In this way, economic growth resulted in improved job opportunities for workers.

\section{(iv) Distribution of employment between private and. public sector}

Between 1963 and 1973, the public sector's share of total employment increased from $13.3 \%$ to $15.3 \%$. This was not due to nationalizations of industries and the takeover of their labor forces by the public sector, since the economy remained largely in private hands. Rather, the increase in public sector employment reflects a tendency of successive governments to increase employment at a rate in excess of labor force growth in order to try to maintain high rates of employment (and possibly also, political support). The growth of public sector employment is a positive development for the workers involved, because the public sector pays wages that are about twice as high as those paid in the private sector.

\section{(v) Occupational distribution of employment}

If economic growth is successful in improving job opportunities for workers, we would expect to find an increase in the proportions of workers employed in the better occupational categories. Indeed, this took place in Costa Rica. The changes in occupational composition of the labor force in Costa Rica between 1963 and 1973 are shown in Table 2.

These data show that the largest percentage increases in employment took place in the highest- paying occupations a clear sign that those occupations expanded in response to the heightened level of economic activity. This was facilitated by an important change taking place on the supply side of the labor market. 
Between 1963 and 1973, the Costa Rican labor force became markedly better educated. The proportion without education fell from $15 \%$ to $10 \%$, the proportion illiterate fell by virtually the same percentages, and the proportion with just one to three years of primary education fell from $37 \%$ to $26 \%$. At the same time, the proportion with four to six years of primary education increased from $37 \%$ to $45 \%$, the proportion with secondary education from $9 \%$ to $16 \%$, and the proportion with university education from $2 \%$ to $4 \%$. Part of this improvement in educational qualifications of the labor force was the natural result of the retirement from the labor force of older, uneducated workers. But of

Table 1. Changes in employment by economic spetor, 1963-73

\begin{tabular}{|c|c|c|c|}
\hline Sector & $\begin{array}{c}\% \text { of } \\
\text { employment } \\
1963\end{array}$ & $\begin{array}{l}\% \text { Change in } \\
\text { employment } \\
1963-73\end{array}$ & Mean income, 1971 \\
\hline Agriculture & 49 & +10 & 793 \\
\hline Mining & 1 & +40 & 1.372 \\
\hline Manufacturing & 11 & +54 & 1,213 \\
\hline Construction & 6 & +68 & 1,203 \\
\hline Commerce & 10 & +75 & 1,539 \\
\hline Services & 17 & +75 & 1,624 \\
\hline Other & 6 & +228 & $1,1,34$ \\
\hline Total & 100 & +48 & \\
\hline
\end{tabular}

Source: Censuses of Population, 1963 and 1973, as cited in Fields (1980, Table 6.3).

Table 2. Changes in occupational distribution of employment, 1963-73

\begin{tabular}{lcc}
\hline Occupational category & $\begin{array}{c}\% \text { Change in } \\
\text { employment, } \\
1963-73\end{array}$ & $\begin{array}{c}\text { Approximate } \\
\text { median income } \\
1973\end{array}$ \\
\hline Professional and technical workers & +126 & $2,60 \mathrm{~K})$ \\
Managers & +88 & 1,800 \\
Office workers & +62 & 1.600 \\
Storekeepers and vendors & +52 & 1.200 \\
Farmers, cattlemen, etc. & +11 & not available \\
Other & +83 & 700 \\
Total & +48 & 800 \\
\hline
\end{tabular}

Source: Censuses of Population. 1963 and 1973, as cited by Fields ( 1980. Table 6.3).

considerable importance was the entry into the labor force of new, well-educated workers, a phenomenon enabled by the growth of school systems at all levels. Between 1960 and 1970, the higher education enrollment rate doubled from 0.05 to 0.10 and the secondary enrollment rate rose from 0.21 to 0.28 ; primary school enrollment was virtually $100 \%$ (UNESCO, 1976).

\section{(vii) Real wages}

Statistics on changes in real wages in the 1960s are not directly available. We may, however, examine changes in average 
absolute income of households, if we assume, as does Cespedes (1973), that the income distribution estimates derived from the Surveys of Family Income and Expenditures in 1961 and 1971 are directly comparable. These data show that average absolute income increased by $58 \%$ in the 1960 s.

\section{(viii) Income inequality}

Income inequality data are available for 1961 and 1971 in the work of Cespedes (1973). Generally speaking, these data indicate that income inequality declined during that time. The income shares of most poor groups increased while those of most rich groups decreased. However, though most poor groups increased their income share, not all did - in particular, the poorest $10 \%$. This creates a measurement problem: how income inequality is perceived to change may depend on which inequality index one uses. ${ }^{1}$

The most commonly-used index of income inequality is the Gini coefficient. By this index, income inequality among families in Costa Rica declined substantially - from 0.52 in 1961 to 0.45 in 1971. No other Latin American country registered so large a decrease in inequality or so low a level of inequality as did Costa Rica in $1971 .^{2}$

\section{(ix) Absolute poverty}

The concept of absolute poverty is based on real (i.e., inflation-adjusted) incomes. Those whose incomes are below some level of real purchasing power are termed the "absolutely poor." This income amount is called the "poverty line." An economy is said to have reduced absolute poverty if the fraction of people receiving real incomes below the poverty line gets smaller over time.

Given the rapid economic growth that took place in Costa Rica, the improvements in job composition that were recorded, and the decrease in income inequality, we would expect that absolute poverty would have fallen substantially. Indeed, it did. In Costa Rica, between the early 1960s and early 1970s, the proportion of households who were poor fell about in half: from $20 \%$ to $10 \%$ if a poverty line of 250 constant (1971) colones is used and from $65 \%$ to $30 \%$ if a poverty line of 500 constant colones is used. Thus, we see that the Costa Rican economy succeeded admirably in raising large numbers of people out of poverty.

\section{(d) Summary}

The Costa Rican economy began the 1960s with real national income of $\$ 336$ per capita. The policies of earlier years were changed and a policy of regional import-substitution within the Central American Common Market was initiated. Rapid economic growth ensued, enabling real national income to double between 1960 and 1971. The workers of Costa Rica benefited substantially. Employment expanded apace with growth of the labor force, leaving the unemployment rate effectively unchanged. However, the mix of employment improved in favor of better, higher-paying activities. Real wages of workers in Costa Rica grew by about $60 \%$. Thus, the rapid economic growth of the type experienced by Costa Rica in the 1960s and early 1970s led to a better mix of jobs and higher rates of pay. Such broad-based economic growth led to reductions in income inequality and absolute poverty.

We may conclude from these data that the workers of Costa Rica benefited and benefited handsomely from the rapid 
growth of the type which their economy enjoyed in the 1960s and early 1970s.

\section{Growth in the 1970s}

We begin our discussion in 1973, the year the previous section left off. From then until the end of the 1970s, Costa Rica enjoyed general prosperity, quite unlike the tumultuous events that were to follow.

1973 was the year of the last published Census of Population. (Another census was taken in 1984 but the results have not yet been published.) However, a program of Household Surveys, conducted regularly every four months, was begun in 1976. These surveys are deemed to be comparable with the Census. Consequently, for our examination of labor market events, we take the 1973 Census as the benchmark year and use the Household Surveys to measure changes in economic conditions.

\section{(a) The macroeconomic environment}

In the 1970s, the Costa Rican economy continued its economic growth, albeit at a slower rate than before. Whereas Gross National Product had been increasing at a real annual rate of 7.0\% between 1965 and 1970, the growth rate averaged only 6.0\% per year from 1970 to 1975 and slowed further to 5.2\% between 1975 and 1980 .

Why did the growth rate slow down but remain as high as it did? Like other countries that depend upon imported energy, Costa Rica was hit hard by the first oil shock of 1973-74. The Costa Rican economy would have experienced very serious difficulties at that time had it not been for a very fortunate external development - a large rise in the world price of coffee, Costa Rica's chief export earner. This temporarily enabled Costa Rica to avert adjustments in her economic position. Coupled with this was the fact that external credit was amply available, due in part to the very same oil price shock that had been a major cause of Costa Rica's economic difficulties in the first place. For a while, it was possible to continue at high levels of economic activity. However, the economy reacted as if the high price of coffee were permanent. Consumption, imports, and government spending all increased substantially; aggregate demand was $25 \%$ higher in 1977 than in 1975.

Alas, these levels could not be sustained. In 1977, world coffee prices started a sharp decline, the cumulative effect of which was a 45\% drop between 1977 and 1981. Between 1978 and 1981, losses due to deterioration of the terms of trade amounted to one-third of GDP (Gonzälez-Vega, 1984). The economy nonetheless tried to sustain the unprecedentedly high level of aggregate demand. Government deficits were large. Domestic savings were low, in part because the government maintained negative real interest rates. Foreign borrowing and domestic credit expansion were high. Between 1970 and 1981, Costa Rica increased its external debt 14-fold. World interest rates rose, causing the required servicing of the external debt to triple. The second oil shock (1979-80) added to the required outlays for imports. Political events in other Central American countries seriously disrupted the Central American Common Market, to which $80 \%$ of Costa Rica's manufactured exports had been going. Foreign investors were fearful of investing in Latin America and foreign capital was less available for loans. The net foreign exchange position of the country was nearly negative. All in all, the country's balance of trade and balance of payments positions were very poor. And yet, for as long as possible, political 
considerations led the government of Costa Rica to refuse to adjust. But the overvalued exchange rate caused exports to deteriorate further and subsidized capital flight, as Costa Ricans themselves put their money elsewhere. As the 1970s came to an end, so too did a chapter of Costa Rica's economic history. The country was faced with an inevitable adjustment when it could borrow no longer. We shall investigate the adjustment period in Section 4.

\section{(b) Changes in labor market conditions in the 1970s}

What happened to key labor market and income distribution variables during this phase of economic growth? The labor market information for the period $1973-80$ is more limited and income distribution information is not available at all. Still, the available data reveal that the positive labor market developments of the 1963-73 period indeed continued through the remainder of the 1970s.

\section{(i) Unemployment}

The unemployment rate, which had been at $7.3 \%$ of the labor force in 1973 , fell thereafter. Unemployment was $6.3 \%$ in 1976, 4.6\% in 1977 and 1978, and 4.9\% in 1979. This occurred despite a labor force growth rate of $4.0 \%$ - a high figure for any country to have to deal with.

\section{(ii) Employment composition}

The employment growth that took place between 1973 (May) and 1980 (July) amounted to 180,600 new jobs. Of these, 47,800 were in the industrial sector and 59,300 in the public sector, due in large part to the growth of parastatals. These were relatively well-paying jobs. Meanwhile, agriculture (the lowest-paying sector) lost 9,100 jobs. These figures indicate that the mix of employment continued to improve in the 1970s, much as it had before.

\section{(iii) Underemployment}

Beginning with the fJousehold Surveys in 1976, data on underemployment began to be published. "Underemployment" consists of visible and invisible underemployment. "Visible underemployment" refers to those individuals who were employed but did not work for a "normal" week and wished to work longer. "Invisible underemployment" includes those individuals whose weekly earnings were less than the national minimum despite working 47 or more hours per week. The data show that underemployment was $9.0 \%$ of the labor force in $1976,7.5 \%$ in $1977,7.6 \%$ in 1978 , and $9.6 \%$ in 1979 . As with the unemployment data, the continued improvement through 1978 and the worsening in 1979 show that the labor market was already feeling the stress of macroeconomic pressure.

(iv) Real wages ${ }^{3}$

Real wage data are not available for the Costa Rican labor force as a whole in this period. However, information is available for that subset covered by Social Security. For those workers, real wages fell by $13 \%$ between 1972 and 1975 , due to the oil price shock and consequent inflation which took place in the Costa Rican economy at that time. But as economic growth resumed, and world coffee prices peaked, real wages grew by $30 \%$ during the rest of the decade. Costa Rican workers were once again participating in economic growth by enjoying higher real wages. 


\section{(v) The growth of public employment}

One other development that took place in the 1970s bears mention: the continued growth of the share of employment accounted for by the public sector. Whereas the public sector provided $15.3 \%$ of total employment in 1973 , it provided $16.8 \%$ of employment by 1976 and $18.5 \%$ by 1979 . This reflects a policy in effect though not explicitly articulated at the time - for the public sector to countervene the limited labor absorption taking place in other sectors in order to maintain employment at high levels. One reason for this was the strength of public sector unions, which are the most powerful in the country. These unions apparently had the ability to keep public sector employment growing at a faster rate than private sector employment while maintaining public sector wages at double the private sector level.

\section{(c) Summary}

Macroeconomic activity, though slower in the 1970s than before, continued at reasonably high levels. Meanwhile, labor market conditions continued to improve. Unemployment and underemployment fell, the mix of employment continued to improve, and real wages rose, signifying labor's continued participation in economic growth. However, in the latter half of the 1970s, external events had turned against Costa Rica, both on the import side and on the export side. Adjustment to the new circumstances was postponed as long as possible. A severe downturn lay ahead.

\section{The Crisis of 1980-82}

\section{(a) The macroeconomic environment}

As the decade of the 1980s began, the economy of Costa Rica was set for an economic downturn that simply could not be avoided. The Costa Rican economy was devastated by the combined effects of balance of payments deficits, rising debt service requirements due both to larger debt and to higher international interest rates, inability to borrow to meet payments, rising import prices, falling export prices, and the world recession in the United States and Europe, which reduced the demand for traditional Costa Rican exports. Net international monetary reserves became negative in 1980. This left Costa Rica with no option but to begin the painful process of economic contraction which they had been trying so long to forestall.

The first step in adjustment was devaluation. In September 1980, the overvalued level of the colon could no longer be sustained and it was left to float. The colon quickly fell from 8.54 to the dollar before the devaluation to 38 to the dollar by the end of 1981 to 65 to the dollar by mid- 1982 .

For a country as reliant on trade as Costa Rica, the devaluation had two important contractionary effects. First, it raised the price of imported consumer products, lowering standards of living on that account. But in addition, devaluation meant that imported inputs were now more expensive. It is estimated that for every dollar of manufactured exports, Costa Rica relies on 80 cents of imported inputs. Thus, the export sector was also hurt by devaluation (although devaluation made the exports themselves cheaper).

In 1980, Costa Rica reached an agreement with the International Monetary Fund (IMF) intended to stabilize the economy. But the country quickly found itself unable to meet the terms of the agreement, so it became inoperative. 
Instead, the Costa Rican authorities suspended payments on the foreign debt. The result of this action was to completely cut off any inflow of new funds. With virtually no official external support, no private external support, or no domestic savings available to finance the deficits, the only policy options available were to cut imports and print money.

The net outcome of all this was a sharp economic contraction. Gross domestic product stagnated in 1980 (real growth of just $0.8 \%$ ), fell in 1981 by $2.3 \%$, and fell in 1982 by $9.1 \%$. In per capita terms, the declines amounted to $1.6 \%$ in 1980 , 4.9\% in 1981, and 11.3\% in 1982. Per capita consumption in 1982 fell to the real level it had been at in 1966. Imports fell from US $\$ 1.5$ billion in 1980 to US $\$ 0.9$ billion in 1982. As domestic interest rates remained unchanged in nominal terms but inflation accelerated, real interest rates became negative, shrinking domestic financial savings. Private investment fell by more than half: from 1.6 billion constant (1966) colones to 0.7 billion. Public debt reached $400 \%$ of exports. Inflation, which had always been low in Costa Rica, went out of control: $37 \%$ in 1981, and $90 \%$ in 1982 . Productivity, as measured by average industrial product per worker, was 44\% lower in 1982 than at its peak in 1977. No wonder the term "crisis" is used to describe this period!

\section{(b) Changes in labor market conditions in the crisis}

The crisis brought a deterioration in labor market conditions that was as severe as it was widespread. Among the unfavorable developments that occurred were:

\section{(i) Worsening of unemployment and underemployment}

Open unemployment more than doubled. The unemployment rate was 3.0\% in November 1979; it reached $8.7 \%$ in November 1981. The corresponding figures for March were 4.6\% (1980) and 9.5\% (1982). (Unemployment always increases from November of one year to March of the next because of seasonal variations in the labor force.)

In addition, unemployment also became severe in that the duration of unemployment significantly lengthened. This is shown in Table 3.

Another aspect of unemployment that bears mention is that the reasons for unemployment changed. Whereas in 1979, $65.7 \%$ of unemployment was accounted for by job-losers or job-leavers, the rest being new entrants to the labor force, by

Table 3. Duration of unemployment in different yoars (November)

\begin{tabular}{lccccc}
\hline Year & $\begin{array}{c}\% \text { Less than } \\
\text { one month }\end{array}$ & $\begin{array}{c}\% \\
\text { One to two } \\
\text { months }\end{array}$ & $\begin{array}{c}\text { Two to four } \\
\text { months }\end{array}$ & $\begin{array}{c}\text { Four months } \\
\text { to one year }\end{array}$ & $\begin{array}{c}\text { More than } \\
\text { one year }\end{array}$ \\
\hline 1979 & 62.8 & 19.6 & 12.4 & 3.7 & 1.5 \\
1980 & 40.2 & 24.7 & 16.6 & 13.3 & 5.3 \\
1981 & 36.7 & 18.2 & 16.9 & 17.0 & 11.3 \\
1982 & 31.2 & 18.6 & 18.0 & 21.1 & 11.1 \\
\hline
\end{tabular}

Source: Encuesta Nacional de Hogares.

$1982,86.3 \%$ of the unemployed were in that category. More people were unemployed, and a larger percentage of those unemployed were in that category, because of deficient demand for their labor rather than for frictional reasons. ${ }^{4}$ 
Turning now to underemployment, these rates increased as well between 1980 and 1982, the March figures showing an increase from $8.8 \%$ in 1980 to $11.8 \%$ in 1982 and the November figures from $8.1 \%$ in 1980 to $13.5 \%$ in 1982.

Combining the figures on open unemployment with those for underemployment, the data indicate that total labor underutilization increased from $10.6 \%$ of the labor force in November 1979 to $20.2 \%$ in November 1982 . These figures show that many workers in Costa Rica suffered by being openly unemployed, having lost their jobs and not being able to find new ones, while many others suffered reductions in the demand for their labor. The burden of economic adjustment fell disproportionately and harshly on these people.

Below, we shall examine which economic sectors suffered the greatest reductions in employment.

\section{(ii) Real wages}

As bad as were the effects of the crisis on unemployment and underemployment, the effects on real wages were worse. Between 1979 and 1982, average real wages in Costa Rica fell by 40\% - an extraordinarily damaging occurrence. As shown in Table 4, the cuts were shared in equal proportion in the private and public sectors. This table also demonstrates that real wages were at their lowest in 1982. This was the year in which two macroeconomic events were particularly unfavorable: real GNP fell the most in 1982, and inflation was at its highest in 1982. The fall in real GNP (by 9.1\%) implied a fall in demand for labor and a consequent deterioration in real wages. On the other hand, the very high inflation of 1982 (90\%) also caused real wages to decline but this decline was in part artificial - the reason being that many wages in the Costa Rican economy are set institutionally and were not adjusted rapidly enough to keep up with inflation. For instance, the minimum wage was adjusted only three times in 1982, and public sector wages likewise were adjusted only three times. Because inflation was proceeding so rapidly, the wage adjustments failed to keep pace, and real wages fell. But this fall was not permanent - real wages recovered by some 15\% in 1983, not because the economy grew significantly (GDP growth in 1983 was only $0.8 \%$ ) but rather because wages were adjusted through the National Wages Council, the

Budgetary Authority, and collective bargaining agreements to catch up with past inflation. Still, real wages were much lower in 1983 than they had been in 1979. They have not caught up since.

In short, the workers of Costa Rica suffered real wage cuts of some $25 \%$ as a result of the economic crisis. And this is among those who were still working. Many, however, became unemployed, hence were not working. For them, the wage cut was very much greater. It is a tribute to the democratic tradition of Costa Rica that the political system remained intact after so severe and widespread an economic deterioration among the masses.

\section{(iii) Labor force participation}

Economic theory predicts that when labor market conditions change significantly, as was the case in Costa Rica when unemployment and underemployment doubled and real wages fell by $25 \%$, that the rate of labor force participation in the economy will change. The direction of the change is ambiguous, however, depending upon the strength of the discouraging effect of jobs being harder to find compared with the inducement of additional family members to enter the labor force to supplement lost earnings. In the 1980-82 crisis in Costa Rica, what happened is that the labor force 
Table 4. Average real wages in Costa Rica

\begin{tabular}{lcc}
\hline Year & Private sector & Public sector \\
\hline 1979 & 1,703 & 2,526 \\
1980 & 1,282 & 2,359 \\
1981 & 1,172 & 2,257 \\
1982 & 985 & 1,684 \\
1983 & 1,027 & 2,189 \\
\hline
\end{tabular}

Source: Central Bank.

participation rate grew - that is, on balance, more additional workers were drawn into the labor force than were discouraged by higher unemployment. In November, 1979, just before the crisis, the labor force participation rate (defined as the number employed plus unemployed, divided by total population) was $35.9 \%$. In November 1981 , the rate was $38.7 \%$ - a remarkable increase in so short a time. Household heads continued their nearly full labor force participation: $99.1 \%$ in $1979,99.8 \%$ in 1982 . Meanwhile, non-heads of household increased their labor force participation, from $57.3 \%$ to $63.5 \%$ in the case of men and from $23.6 \%$ to $26.7 \%$ in the case of women. The result was an increase in the Costa Rican labor force from 784,000 to 885,000 persons in two years. As a result, in 1981 and 1982, twice as many persons in the labor force were seeking work for the first time as was the case in 1979 and 1980.

The increase in the rate of labor force participation has an important bearing on the interpretation of labor market events in the crisis. It means that the economy was called upon to provide an unprecedented number of new jobs if it was to absorb the large number of additional workers offering their services. It becomes important, therefore, to look at the growth of employment overall and in particular economic sectors to see how they fared in the crisis years.

\section{(iv) Employment growth}

The figures on employment growth shown in Table 5 reveal a surprising pattern: in the worst years of the crisis (1982), employment in the Costa Rican economy grew by 5.0\% - more than in the previous three years combined. Quite a number of the secondary workers who were entering the labor force at the depths of the crisis were finding some kind of work.

What kind of work was it? It might be thought that employment would have expanded largely in the categories that are easiest to enter - non- remunerated family worker, self-employed worker, and employer. But here again, the figures are surprising: all of the increase in employment was in the category of wage employee (Table 6). Apparently, the supply of additional workers at lower real wages enabled employers to hire more workers. Contrary to the inferences drawn by some, it does not appear that the crisis led to an overall reduction in the demand for labor.

What did happen was that the composition of employment worsened, as described below.

\section{(v) Employment composition}

In the crisis years, the mix of employment shifted in favor of the poorer jobs, reversing the improvements that had been taking place for two decades: 
Industrial mix $\mathrm{x}^{5}$ The largest gain in employment was in agriculture. This accounted for $80 \%$ of new job creation, and occurred principally among non-heads of household (Pollack, 1985). Three-quarters of the income in agricultural employment was in wage employment, one-quarter in unpaid family employment (MIDEPLAN, 1984, Table 9). But the agricultural sector has the lowest wages of any sector in Costa Rica, so these were hardly good jobs. Personal services accounted for $60 \%$ of employment growth, as this is a high-paying sector, this change can be interpreted more favorably. The balance (minus 40\%) is taken up by manufacturing, construction, and basic services, which lost jobs during the crisis.

Occupational mix: During the crisis period, the top occupational classes lost importance, reaching their lowest levels in 1982 (Table 7). In this way as well, the labor market worsened in the crisis.

Informal sector employment: Informal sector employment increased both absolutely and relatively. Pollack (1985) and MIDEPLAN (1985) have defined the informal sector in Costa Rica as persons with low levels of education running or working in small establishments. By this definition, informal sector employment increased by 20,000 persons, from $27.7 \%$ of the total in Costa Rica in 1979 to $29.2 \%$ in 1982. The Ministry of Planning characterizes the role of the informal sector thus: "The existence of the informal sector is explained by the limited capacity of the formal sector to absorb the increment in the labor force ..." (MIDEPLAN, 1985, p. 2, translation mine). By this characterization, the growth of the informal sector reflects poor formal sector employment opportunities. This is how it is usually seen. But this story has another side to it. As Pollack and Uthoff (1984) showed for workers with given education and experience, wages in the informal sector fell

Table 5. Annual rates of growth of employment, unemployment, and labor force

\begin{tabular}{lccc}
\hline Year & $\begin{array}{c}\% \text { Employment } \\
\text { growth }\end{array}$ & $\begin{array}{c}\% \text { Unemployment } \\
\text { growth }\end{array}$ & $\begin{array}{c}\% \text { Labor force } \\
\text { growth }\end{array}$ \\
\hline $1976-77$ & +6.4 & -23.6 & +4.5 \\
$1977-78$ & +5.6 & +5.4 & +5.6 \\
$1978-79$ & +3.3 & +10.5 & +3.7 \\
$1979-80$ & +0.9 & +22.8 & +2.0 \\
$1980-81$ & +0.5 & +53.0 & +3.6 \\
$1981-82$ & +5.0 & +14.3 & +5.8 \\
\hline
\end{tabular}

Source: Céspedes et al. (1984, p. 53).

Table 6. Employment by occupational category, 1979 and 1982

\begin{tabular}{lrr}
\hline & 1979 & \multicolumn{1}{c}{1982} \\
\hline Wage-earner & 514,964 & 567,289 \\
Independent worker & 123,842 & 120,890 \\
Employer & 27,339 & 32,189 \\
Family worker & 40,990 & 39,511 \\
& 707,135 & 759,879 \\
\hline
\end{tabular}

Source: Pollack (1985, Table 9),

by relatively less in the crisis than did formal sector wages. This suggests a more positive scenario: that workers were 
entering informal sector employment, because wages were holding up relatively well there. This more favorable scenario is supported by interviews with informal sector workers. Nearly all informal sector workers report themselves there voluntarily. Perhaps, the increased importance of informal sector employment is not all that bad.

Job upgrading: Pollack and Uthoff (1984) indicate that within given job types, skill requirements were upgraded during the crisis. ${ }^{6}$ This means that given a worker's education and experience, wages fell by even more than the economy-wide average. One reason wages did not fall even further is that some employers substituted relatively better-educated workers in place of less-educated ones when they had the opportunity.

Public/private: In the crisis years, private sector employment grew by about $10 \%$ and public sector employment fell by about $5 \%$. Consequently, the private sector came to account for a larger percentage of total employment, reversing the long-term trend for the public sector's share to increase. The public sector pays higher wages than the private sector; so from the workers' perspectives, the falling share of public sector employment represented a worsening of job opportunities.

\section{(vi) Poverty}

It would be expected that with a doubling of unemployment and underemployment and a $25 \%$ fall in real wages, the Costa Rican economy would have experienced a sharp increase in absolute poverty. Indeed it did. Pollack $(1985$, p. 10) shows that the proportion of income recipients earning less than a constant real minimum wage increased from $25.5 \%$ in 1979 to $32.5 \%$ in 1982 . Might this gross increase have been due to the presence of large numbers of additional workers

Table 7. Distribution of employment by occupational category

\begin{tabular}{|c|c|c|c|c|c|c|}
\hline & $\begin{array}{l}\% \text { Professional } \\
\text { and technical }\end{array}$ & $\begin{array}{l}\% \text { Administrative } \% \\
\text { and managerial }\end{array}$ & $\begin{array}{l}\text { Employers } \\
\text { and sales }\end{array}$ & $\begin{array}{l}\text { s\% Operatives } \\
\text { and artisans \% }\end{array}$ & Services & $\begin{array}{l}\% \text { Unknown, } \\
\text { first time job } \\
\text { seekers }\end{array}$ \\
\hline Novcmber 1979 & 8.3 & 12.6 & 12.8 & 51.7 & 13.8 & 0.8 \\
\hline November 1980 & 7.9 & 12.0 & 13.6 & 50.8 & 14.3 & 1.4 \\
\hline November 1981 & 7.8 & 10.8 & 13.2 & 51.4 & 14.4 & 2.5 \\
\hline November 1982 & 7.4 & 10.3 & 12.8 & 52.9 & 14.7 & 1.8 \\
\hline November 1983 & 7.7 & 11.4 & 13.7 & 50.3 & 15.5 & 1.4 \\
\hline November 1984 & 9.0 & 11.2 & 14.2 & 46.6 & 15.6 & 1.4 \\
\hline
\end{tabular}

who entered the labor force at the lowest pay levels? Disaggregated data presented by Pollack suggest not. Among household heads (more than $99 \%$ of whom were labor force participants throughout the crisis period), the poverty rate increased from $24.4 \%$ to $30.8 \%$. Also, poverty rates increased in all educational categories (Table 8). Diets worsened, as did the basic basket of goods consumed by wage-earners. More specifically, in the crisis years, Costa Ricans consumed less milk and meat, and their use of gasoline and cement also declined (Cespedes et al., 1985, Table f2). Absolute poverty indeed grew worse in Costa Rica in the economic crisis.

(vii) Inequality

During the economic crisis, what happened to income inequality? Some observers might reason that those who had the most to lose would have lost the most, and consequently, that inequality would have narrowed. Others might have 
thought the opposite: that with rapidly rising unemployment and with rapidly falling real wages, those without jobs and those who were forced to take poorer ones would have lost the most, and that this would have increased inequality. The evidence is mixed.

Cespedes et al. (1983, p. 67) analyzed national accounts statistics and found that the functional distribution of income shifted against labor and against factors of production as a whole. On the surface, this would suggest that the share of profits in GNP had increased in the crisis at the expense of labor's share. But such a conclusion would be premature. This is because national income itself fell as a percentage of GNP, from $79 \%$ before the crisis to $70 \%$ afterwards. This means that more of the GNP left the country in the crisis than before. Among the mechanisms responsible were foreign debt payments, repatriation of foreign capital, flight of local capital, and remittances by Costa Rican and other nationals to family members abroad. Supplementary statistics show that the remuneration of wage and salary workers as a proportion of national income fell by less than did GNP - from 63\% in 1979 and 1980 to $58 \%$ in 1982 - but then went up to $65 \%$ in 1983 and 1984 (Cespedes et al., 1985, p. 13). We may thus conclude that except for the one year, 1982, the functional distribution of income in Costa Rica did not turn against labor vis-ä-vis capital. It did, however, turn against domestic as opposed to foreign income recipiency.

\begin{tabular}{|c|c|c|}
\hline Education level & $\% \quad 1979$ & $\% \quad 1982$ \\
\hline None & 47.7 & 63.4 \\
\hline Primary & 28.3 & 36.6 \\
\hline Secondary & 8.4 & 10.3 \\
\hline University & 0.0 & 1.3 \\
\hline
\end{tabular}

Source: Pollack (1985, p. 10).

${ }^{*}$ Poverty line $=$ minimum wage.

One other aspect of the functional distribution of income bears mention: whereas wage income as a percentage of national disposable income was 48\% in 1977 and 55\% in 1980, it was down to 51\% in 1982 and 46\% in 1983 (MIDEPLAN, 1984, p. 12). Labor lost income share relative to government, in large part because of sharply higher social security payroll taxes instituted in 1982.

Turning now to personal income inequality, the available information is limited, and what we have presents a mixed picture. The Instituto de Investigaciones en Ciencias Economicas of the Universidad de Costa Rica estimates from the household surveys that the Gini coefficient of income inequality increased from 0.44 to 0.47 between 1971 and 1983 . While data were not available for intermediate years, it is the belief of the Institute Director that inequality had fallen until the crisis and risen during it. ${ }^{7}$ Two studies look specifically at the crisis period. Pollack and Uthoff (1984, p. 25) report that the log-variance of inequality of labor income among the employed (another measure of personal income inequality) increased by 0.03 between 1979 and 1982. In contrast, Altimir (1984) reports that the Gini coefficient of income inequality fell from 0.38 to 0.35, also between 1979 and 1982 . 
Unfortunately, then, we are unable to reach any definite conclusion about whether income inequality in Costa Rica increased or decreased in the crisis period.

\section{(c) Relation between labor market changes and international economic conditions}

Several of the findings presented above can be linked up by considering the fact that the macroeconomic decline of 1980-82 entailed a many-fold devaluation of the colon. Devaluation implies that exports are cheaper abroad and that imports are more expensive at home. In Costa Rica, the main exports are agricultural products. These rely almost entirely on domestic resources. As such, they become cheaper in world markets when devaluation takes place. This implies that agricultural production would be expected to have increased in the crisis. Indeed, it did: agriculture was one of the few bright spots in an otherwise dismal economic downturn. Real agricultural product was 6\% higher in 1981 than in 1980, and still marginally higher in 1982. Agriculture's share of GNP were $18.0 \%, 19.3 \%, 20.2 \%$ in $1980-82$. Agriculture is a heavy user of labor in Costa Rica. Consequently, when production in the agricultural sector expands, employment in agriculture expands along with it. In fact, as we have already seen, total employment increased in Costa Rica in the crisis years, the bulk of that employment increase taking place in the agricultural sector. The increased demand for agricultural labor would also tend to offset the decline in wages that was taking place for other reasons. Once again, the evidence is consistent with theory - Pollack and Uthoff (1984, p. 21) having showed that the wages of workers in the exportables sector did relatively better than the wages of workers in the non-tradables and importables sectors (which lost competitiveness due to greater debt and devaluation) or than workers in urban areas generally, in the urban formal sector, or in the modern rural sector.

One might also ask how the manufacturing sector fared, as they account for a significant minority of exports. The main problem facing manufacturing is that Costa Rican production relies heavily on imported inputs. With the devaluation, these inputs became more expensive, or in some cases, impossible to obtain due to lack of foreign exchange with which to purchase them. The manufacturing sector's contribution to real GNP and its share of GNP fell. Its share of employment, however, increased somewhat, due apparently to employers being unwilling to lay off experienced workers (Cespedes et al., 1985, Table 18). And the real wage position of manufacturing improved relative to the average (Cespedes et al., 1985, Table 19).

In sum, the patterns observed in several particular sectors in the crisis can be understood in terms of the effects of international economic events on them. Devaluation of the colon encouraged exports. According to estimates by Pollack and Uthoff (1984, Table 2), in 1981, when total employment was essentially unchanged, employment in the exportables sectors rose by $5.5 \%$; in 1982 , total employment rose by $4,0 \%$, employment in the tradables sectors by $9.4 \%$. Wages in the exportables sector gained on those in others. This reaffirms the economist's maxim that demand for labor is derived from demand for product.

\section{(d) Summary}

The Costa Rican economy experienced a severe economic crisis beginning at the turn of the decade and extending through the end of 1982. Labor market conditions deteriorated precipitously. The rate of unemployment increased by 5 
percentage points and underemployment by several more. However, the major worsening in the labor market took place with respect to real wages, which fell by $40 \%$ in just three years and affected everyone. The labor force participation rate jumped up, as additional workers were drawn into the labor force to help supplement the family income. Consequently, the number employed grew in every year and so too did the number of wage-earners (as versus independent workers or family workers). Long-term trends toward a better mix of jobs were reversed in these years.

Although all sectors of the economy were affected adversely, some were affected more so than others. Those that did less badly were the ones that produced for export. The devaluation of the colon helped them by making their products cheaper in world markets. This linkage between macroeconomic conditions, the country's external economic relations, and the labor market explains why Costa Rica's agricultural sector suffered less badly from the crisis than did other economic sectors.

\section{The Recovery Since 1983}

\section{(a) The macroeconomic environment}

In mid-1982, a new administration took office in Costa Rica. One of the first actions of the new government was to initiate a program of economic stabilization, carried out on its own and facilitated with the help of an IMF agreement reached in December of 1982. Among the policy measures taken then or in the months thereafter were: tightening of monetary policy to control inflation; reestablishment of positive real interest rates, to stimulate investment; a cut in government spending and subsidies, to try to narrow the budget deficit; increases in taxes, among which were the social security tax, also to try to narrow the budget deficit; rescheduling of debt with 10 creditor countries, to permit payments to be made in a more manageable way; attainment of an understanding with commercial bank creditors, also to permit payments from getting out of hand.

The result of these policy measures was indeed the resumption of economic growth that had been sought. The Gross National Product, which had been falling in real terms in 1981 and 1982, again became positive. Real GDP grew by 2.3\% in 1983 and by $6.3 \%$ in 1984. Inflation also came under control, falling from $90 \%$ in 1982 to 32\% in 1983 to $12 \%$ in 1984 . Confidence in the colon was restored, fluctuations in its value dampened, and capital started being repatriated once again. The balance of payments deficit improved: from $14.5 \%$ of GDP in $1980 / 81$ to $9 \%$ of GDP in $1982 / 83$, to $6 \%$ of GDP in 1984 . $^{8}$ Real exports grew by $11 \%$. Capital formation was up by $20 \%$.

In sum, the macroeconomy of Costa Rica is once again moving in an upward direction.

\section{(b) The labor market}

As the macroeconomy has improved, so too has the labor market:

\section{(i) Employment and job composition}

Between July 1982 and July 1984, employment increased by 27,000 jobs. Private sector employment held steady while public sector employment grew by nearly $20 \%$, attaining the highest levels ever. In the recovery period, the mix of jobs resumed its upward trend, after the reversal of same during the crisis. The number of wage and salary employees once 
again grew, while the number of unpaid family workers fell. The occupational composition of employment also has improved, the relative shares of professional and technical employees, administrative and managerial personnel, and sales workers all increasing. By economic sector, agriculture's share of total employment again continued to fall, as workers were bid away from agriculture to other, better paying activities, and the shares of employment accounted for by commerce and services once again increased. As before, the share of manufacturing employment in total employment held constant. These changes, as well as the growth of public sector employment relative to private sector employment, represent a shift into relatively high wage jobs - a sign that labor market conditions are again improving.

\section{(ii) Laborforce}

One sign of labor market distress in the crisis period was the sharp increase in the labor force participation rate, caused by additional workers entering the labor market to supplement the incomes of family members whose economic positions had deteriorated due to unemployment and/or falling real wages. Within the first year of the recovery, the labor force participation rate reverted back to its historic level. The March and November 1983 rates were $34.4 \%$ and $36.3 \%-$ exactly what they were in 1980 . These rates have not changed significantly since.

\section{(iii) Unemployment and underemployment}

The recovery has also brought lower unemployment and underemployment, as shown in Table 9. Unemployment durations fell as the labor market tightened. Also, urban unemployment became a smaller part of total employment. So too did the fraction of unemployed who were first-time job seekers. An unemployment rate of $6.2 \%$ is not particularly worrisome. Rather, the concern of policymakers in Costa Rica is how to create more better-paying jobs.

\section{(iv) Real wages}

The recovery brought rising real wages. The average real wage increase in 1983 was an exceptional 19\%. The 1983 increase was so large, because of catch-ups with $90 \%$ inflation of 1982 . Real wages rose a further $6.2 \%$ in 1984 , exactly in line with that year's growth rate in GNP. Nonetheless, real wage losses in the crisis have yet to be made up; real wages were still 15\% lower in 1984 than in 1979. And these figures fail to reflect the sharp increase in Social Security payroll taxes paid by workers which took effect at the beginning of 1983, lowering their net take- home wages. It will take several more years of strong economic growth before the workers of Costa Rica attain the same living standards as they enjoyed at the end of the 1970s.

\section{(c) Summary}

In order to work its way out of the most serious economic contraction since the Great Depression, Costa Rica undertook major macroeconomic policy reforms beginning in mid-1982. The economy indeed stabilized. Debt payments resumed, exports increased, inflation slowed, investment rose, and GNP grew. The resumption of economic growth had favorable labor market effects. Employment increased, unemployment and underemployment fell, additional workers who had entered the labor force in the crisis returned to their accustomed positions, real wages rose, and the composition of employment improved. Economic growth and improvement in employment conditions once again went hand-in-hand. 
But just as the GNP per capita has yet to reach its pre-crisis level, so too do the workers of Costa Rica remain poorer than before the crisis.

Table 9. Unemployment and underemployment in the recovery

\begin{tabular}{|c|c|c|c|}
\hline $\begin{array}{l}\text { Year } \\
\text { (March) }\end{array}$ & $\begin{array}{c}\text { Number } \\
\text { unemployed }\end{array}$ & $\begin{array}{l}\% \text { Unemployment } \\
\text { rate }\end{array}$ & $\begin{array}{l}\% \text { Underemployment } \\
\text { rate }\end{array}$ \\
\hline 1982 & 78,800 & 9.5 & 11.8 \\
\hline 1983 & 73,400 & 9.0 & 11.1 \\
\hline 1984 & 64,900 & 7.8 & 9.0 \\
\hline 1985 & 53,500 & 6.2 & n.a. \\
\hline
\end{tabular}

Source: CEFSA, Calculated from National Household Survey.

\section{Conclusions and Policy Implications}

\section{(a) Overview of findings}

The economic growth that occurred in Costa Rica for most of the last 25 years has led to improved employment opportunities for workers. Contrarywise, during those years in which a severe economic recession took place (1980-82) labor market conditions deteriorated. Fortunately, recession was the exception rather than rule in Costa Rica. Gross domestic product grew by $6.5 \%$ per annum in the 1960s and by 4.5\% per annum between 1970 and 1982 .

Table 10 documents some of the ways in which economic growth brought improvements in labor market conditions and income distribution. We find:

Unemployment: The open unemployment rate is essentially unchanged. The economy managed to create enough new jobs to keep pace with the growth in labor force.

Employment composition: Not only are more people employed but the percentage mix of jobs has improved in favor of the better-paying categories: wage-earners in place of non-remunerated family workers; professional, technical, managerial, and office workers rather than manual workers; employment in manufacturing and other sectors in place of agriculture; public as opposed to private employment; higher educational categories.

Real wages: On average, the workers of Costa Rica earn about $60 \%$ more now than in the early 1960 s.

Income inequality: Income inequality has fallen in Costa Rica and is among the lowest in Latin America.

Absolute poverty: With economic growth having taken place and income inequality having fallen, absolute poverty also has fallen, the percentage poor today being only a fraction of what it was 25 years ago. ${ }^{9}$

In a nutshell, economic growth benefited the labor market and hence the poor.

\section{(b) Prospects and policies for the future}

The apparent task before the Costa Rican economic authorities is to upgrade employment opportunities as a means of achieving further economic development. This is true regardless of political/military events in the region. 
A stable macroeconomic environment is the sine qua non of new employment generation. If employment conditions are to be improved in a mixed capitalistic economic system such as that of Costa Rica, it is essential that the private sector have confidence in the stability of the economic environment. Not only local entrepreneurs but also foreign capitalists will find it attractive to invest in Costa Rica only if they have reasonable certainty that they will receive at least a fair return on their money. This will not be the case if debts are not serviced, if real interest rates are negative, or if an overvalued colon is in imminent danger of devaluation - all of which took place in Costa Rica in the crisis period. Under such circumstances, local investors will tend to invest abroad and foreign investors will not enter Costa Rica at all. It is essential, therefore, that macroeconomic policy assures a stable environment within which entrepreneurial decisions may be made.

Conditions in Costa Rica are conducive to export expansion. The labor force is well-educated and productive. Labor market policies (about which more shall be said shortly) are on the whole quite reasonable. Other advantages of Costa Rica include its political stability, which makes investment there attractive for foreign and local firms alike, and the incentives for export offered under the US government's Caribbean Basin Initiative.

Two key policy decisions must be made: (1) whether to seek primarily to expand traditional exports (coffee, bananas, etc.) or non-traditional exports (chiefly light manufactured products), and (2) how actively to promote exports through selective public expenditures, tax incentives in certain sectors, and the like, versus a more laissez faire approach.

Table 10. Changes in labor market conditions and income distribution in Costa Rica, 1963 to mid-1980s

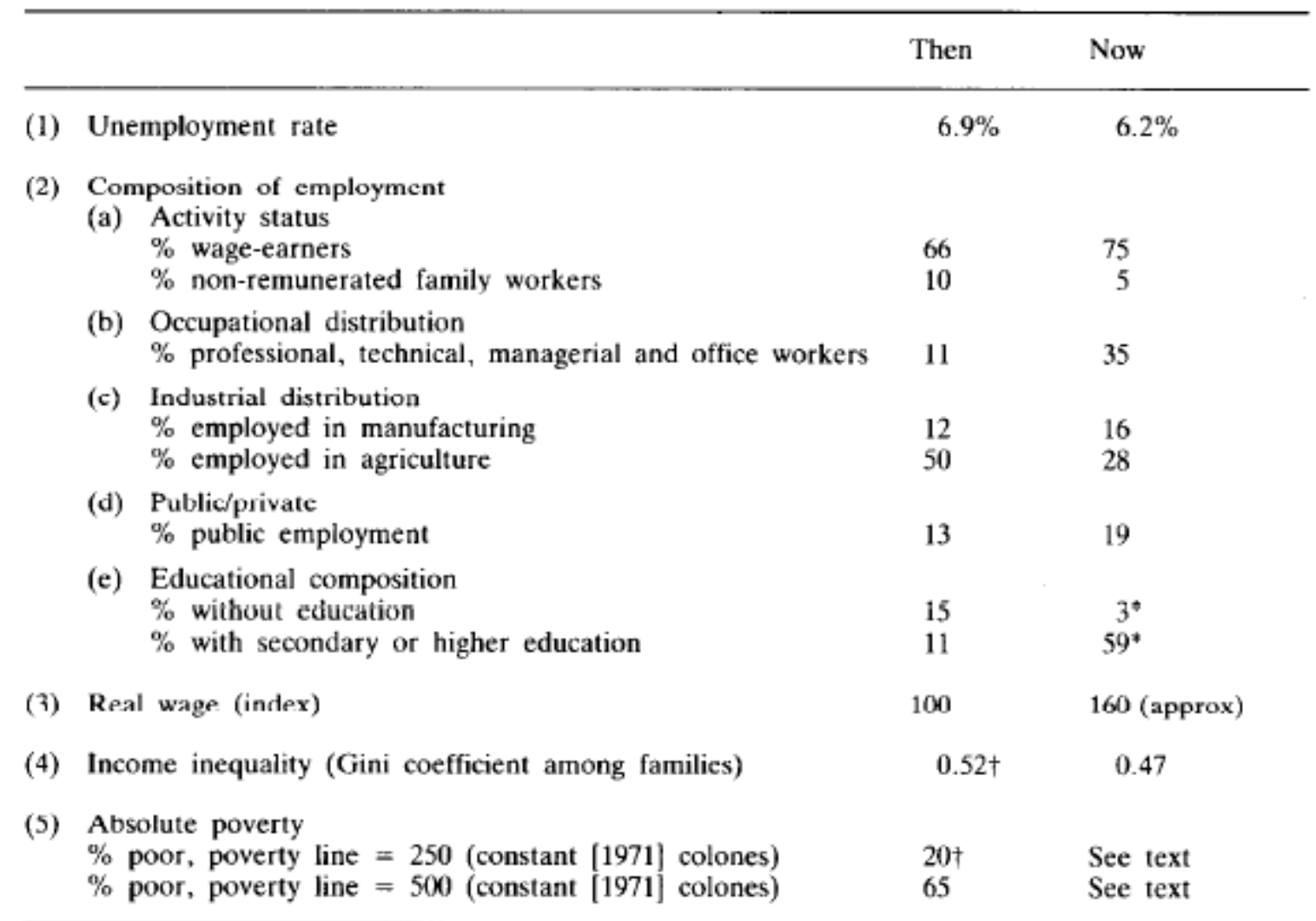

Sources: Calculated by the author from data from the 1963 Census of Population and Housing and National Household Surveys, Céspedes (1973), and Altimir (1984).

*Pereent of employed population.

†Data pertain to 1961 . 
On the matter of choosing what to try to export, the overwhelming emphasis in public policy debate is on nontraditional exports. But in seeking to expand non-traditional exports, the expansion of traditional exports is not precluded. This possibility has not, I think, been given the attention it deserves. Yes, it is true that world prices of many of these products are volatile and that the terms of trade have been moving away from these products. But is also true that Costa Rica has a comparative advantage in producing, say, coffee. And these crops generate badly-needed rural employment. Careful consideration needs to be given to the social costs and social benefits of alternative export products. The issue is not as unambiguously in favor of non-traditional exports as it might seem.

The other issue is how actively to promote exports. (By "export promotion," I mean the active dedication of public resources to expansion of exports.) In economic terms, the only exports that should be promoted are those that cannot get started on their own but that, in the near term, can pay their own way, preferably in the world market but, if not, within what is left of the Central American Common Market. Otherwise, a laissez faire approach is in order. Costa Rica should not spend scarce public resources just to generate foreign exchange, just to diversify into new areas, or just to generate jobs in the export sector. Once again, the decision criterion ought to be that the benefits to society outweigh the costs to society of using resources to stimulate exports. Careful study needs to be made to see that this criterion is implemented.

The key to successful export-led growth in Costa Rica is the private sector. This is partly because the private sector remains the primary employer in the country, accounting for more than $80 \%$ of total employment, and partly because of the dynamism of local entrepreneurs and foreign investors.

In the private sector, wages are set largely in accordance with supply and demand. Unions are present in the Costa Rican economy, but they cover only a small fraction of the private sector labor force; and where unions are present, they do not raise wages all that much above the nonunionized sectors of the economy. Minimum wages also exist in Costa Rica. But the clear guideline used by the minimum wage authority is to keep the minimum wage generally in line with productivity. Thus, in general, a great deal of competition prevails within the private sector labor market in Costa Rica.

\section{(c) Concluding remarks}

The tasks that lie ahead are to sustain the economic recovery while expanding into new areas that will improve job opportunities and raise real earnings for the Costa Rican people. Perhaps the best way of raising standards of living is to enhance opportunities for productive employment in sectors producing for world markets. It is inevitable that Costa Rica participate in the world economy. That participation is both an opportunity and a challenge - an opportunity to sustain existing profitable exports and penetrate new markets, a challenge to design policies that help mobilize financial and human resources to respond to the opportunity. 


\section{Notes}

1. Technically, this is because the Lorenz curves for the 1961 and 1971 income distributions cross.

2. By contrast, income inequality (as measured by the Gini coefficient) was $0.57-0.61$ in Brazil in 1970 and 0.58 in Mexico in 1969 (Jain, 1975).

3. The figures in this paragraph are drawn from Villasuso and Trejos (1982, Table A-16), based on wages reported to the Caja Costarricense del Seguro Social.

4. Deficient demand unemployment denotes a situation where people are unemployed because of a shortage of jobs in the economy. By contrast, frictional unemployment refers to the fact that it takes time for job-seekers to find suitable jobs.

5. The figures in this paragraph were provided by the USAID mission in San Jose.

6. Formally, the way they did this was to run earnings functions based on education, experience, and job characteristics as follows:

$\ln Y i j=a j j+r j S i j+r j^{\prime} E i j+r j^{\prime \prime}(E i j) 2+0_{j} \ln D W i j+u i j$.

where $L n_{i j}$ is the logarithm of income earned by individual $i$ in labor market $j$, Sij is the individual's years of schooling, Eij is the individual's experience, DWij is the number of days worked, uij is an error term, and the other symbols are regression coefficients estimated from the earnings function. They then decomposed the total earnings differential into a part due to differences in compensation within a job type and a part due to difference in job type. In every case, they found that the difference in job types adds to what would otherwise have been a bigger fall. Or viewed the other way, given skill and time worked, remuneration fell even more within segments. It is because of job upgrading that average earnings fell by less.

7. Private interview with Lie. Juan Diego Trejos, 18 October 1985.

8. One interesting footnote: Costa Rica's debt situation would be better were it not for the fact that several member countries of the Central American Common Market, facing balance of payments problems of their own, have not paid Costa Rica some $\$ 300$ million owed on commercial transactions.

9. Though specific figures are not available at present, poverty fell in half in the 1960 s and continued to fall until 1980. Poverty is no higher now than it was in 1976. 


\section{References}

Altimir, Oscar, "Poverty, income distribution and child welfare in Latin America: A comparison of pre- and post-recession data," World Development, Vol. 12, No. 3 (March 1984).

Calvo, MI. Felipe, "Costa Rica: Evolucidn y características de la mano de obra," in Juan J. Buttari (Ed.), El Problema Ocupacional en America Latina (Buenos Aires: Ediciones SIAP. 1978).

CEFSA (Consejeros Econömicos y Financieros S.A.), Cuadros de Empleo y Desempleo (Mayo 1985). Céspedes, Víctor Hugo, Costa Rica: La Distribución del Ingreso y el Consumo de Algunos Alimentos (San

José: Universidad de Costa Rica, 1973).

Céspedes, Víctor Hugo, Ronulfo Jiménez, and Eduardo Lizano, Costa Rica: Crisis y Empobrecimiento (San José: Academia de Centroamérica, 1983.

Céspedes, Víctor Hugo, Claudio González Vega, Ronulfo Jiménez, and Eduardo Lizano, Costa Rica: Estabilidad sin Crecimiento (San José: Academia de Centroamérica, Agosto 1984).

Céspedes, Víctor Hugo, Alberto D. Mare, and Ronulfo Jiménez, Costa Rica: Recuperación sin Reactivaciön (San José: Academia de Centroamérica, Noviembre 1985).

Dirección General de Estadística y Censos, "Encuesta nacional de hogares: Empleo y desempleo," various issues.

Fields, Gary S., Poverty, Inequality, and Development (New York: Cambridge University Press, 1980).

Gonzälez-Vega, Claudio, "Fear of adjusting: The social costs of economic policies in Costa Rica in the 1970s," in Donald Schulz and Douglas H. Graham (Eds.), Revolution and Counter-Revolution in Central America and the Caribbean (Boulder, CO: Westview Press, 1984). Also published in Spanish as Temor al Ajuste: Los Costos Sociales de las Políticos Econömicas en Costa Rica durante la Década de los 70 (San José: Academia de Centroamérica, 1984).

Jain, Shail. Size Distribution of Income: A Compilation of Data (Washington, DC: World Bank, 1978).

MIDEPLAN (Ministerio de Planifiaciön Nacional y Política Económica), La Crisis y la Evoluciön del Empleo y Los Ingresos en Costa Rica (Octubre, 1984).

MIDEPLAN (Ministerio de Planifiaciön Nacional y Política Econömica), Segmentación del Mercado de Trabajo en el Área Metropolitana de San José (Junio 1985).

Pollack, Molly, “Household behaviour and economic crisis, Costa Rica, 1979-1982" (Santiago, Chile: PREALC, September 1985).

Pollack, Molly, and Andras Uthoff, "Analysis Microeconómico del Ajuste del Mercado de Trabajo: Costa Rica, 1979-1982: Lecciones para un Modelo Macroeconómico" (Santiago, Chile: PREALC, Septiembre 1984).

UNESCO, Statistical Yearbook 1976 (New York: UNESCO, 1976).

Uthoff, Andras, and Molly Pollack, "Analysis microeconómico del Ajuste del Mercado de Trabajo de Costa Rica 1979-1982: Lecciones para un Modelo Macroeconómico," Revista de Ciencias Econömicas, Primer Semestre (1985).

Villasuso, Juan Manuel, and Juan Diego Trejos, Evoluciön Reciente de la Estructura Salarial en Costa Rica (San José: Instituto de Investigaciones en Ciencias Econömicas, Universidad de Costa Rica. No. 32, Octubre 1982). 